TECHNICAL TRANSACTIONS 9/2017

CZASOPISMO TECHNICZNE 9/2017

CIVIL ENGINEERING

DOI: $10.4467 / 2353737$ XCT.17.150.7162

\author{
Maria Kośmieja (maria.kosmieja@put.poznan.pl) \\ Jerzy Pasławski (jerzy.paslawski@put.poznan.pl) \\ Institute of Structural Engineering, Faculty of Civil and Environmental Engineering, \\ Poznan University of Technology
}

\title{
A FLEXIBLE APPROACH TO THE EVALUATION OF THE COST EFFECTIVENESS OF INVESTMENT PROJECTS
}

OCENA EFEKTYWNOŚCI FINANSOWEJ PRZEDSIĘWZIĘĆ INWESTYCYNYCH.

PODEJŚCIE ELASTYCZNE

\begin{abstract}
This article presents basic ideas for flexible design in construction investments through the presentation of methods used for assessing the financial effectiveness of investments. The classification of these methods based on two main factors, time and risk, is shown. The authors propose an algorithm for the analysis of the economic efficiency of projects implemented in a flexible manner.
\end{abstract}

Keywords: economic efficiency, flexibility, risk

\section{Streszczenie}

W artykule przedstawiono podstawowe idee elastycznego projektowania w budownictwie. Omówiono metody oceny efektywności finansowej przedsięwzięć inwestycyjnych. Pokazano podział tych metod ze względu na dwa najważniejsze czynniki: czas i ryzyko. Zaproponowano algorytm postępowania podczas analiz efektywności ekonomicznej przedsięwzięć realizowanych w sposób elastyczny.

Słowa kluczowe: efektywność ekonomiczna, elastyczność, ryzyko 


\section{Introduction}

Today's accelerating rhythm of life causes pervasive changes in the world around us, including demography, migration, conflicts, complex interaction of systems. The consequence of such phenomena of rapid technological and material progress and globalisation is the disorder of traditional market structures. Future events are becoming more difficult to predict, even in the case of the fairly near future.

Therefore, strategies taken by companies should be flexible so that they will be able to follow the changes in the environment and allow taking advantage of the appearing opportunities in an uncertain environment.

The traditional approach to project planning is becoming obsolete due to it being based on assumptions of analytical thinking and the evaluation of the probability of an event - this is insufficient when the future becomes more and more unpredictable.

Therefore, this justifies the introduction of a new approach based on flexibility understood as the possibility (but not a necessity) to introduce some options assuming change of the configuration parameters of the system or its components over time [7].

The purpose of research is demonstrating the profitability of the application a flexibilities in the engineering planning on the example of construction investments. Moreover, analysis of a few differing cases is supposed to enable the development of a procedure which allows the assessment of the possibilities of applying various flexible options. Apart from the typical economic criterion (taking into account e.g. NPV, IRR) also should be possible to taking into account conditioning associated with different criteria (e.g. technical specifications, quality and ecology).

The purpose of this article is to review the specifics of the situation in the analysis and provide an evaluation of the possibility of introducing a flexible approach when planning infrastructure investments and to propose an algorithm or set of procedures of conduct in this field based on the method of scenarios. The following scheme (Fig. 1) shows a sequence of operations for introducing the flexibility of an investment. To begin with, we are checking whether in the project, the flexibility can be led, we are assessing the risk, tactics and appropriate strategies in this way in order to identify elements that will enable the elimination of risk. Generating three scenarios, different from each other in sizes of individual essential parameters is next action (e.g. traffic loading, the height of users or the fall in this parameter). Next, after performing appropriate simulations, we receive the best plan of action for the given investment.

Classical methods for the financial evaluation of economic efficiency, which are based on updated cash flows, have become inadequate for the proper assessment of projects, which are based on flexibility, understood as the ability to modify investments during the entire life. These methods are also not able to correctly assess opportunities that may open up in the future, before undertaking a result of taking a particular action. This is happening this way, because the traditional methods require that during planning of the investment project and assuming its course companies predict the future (which in many cases impossible), and on that basis irreversible decisions about the future shape of the project are made [3] In addition, 
during the definition of an investment project and the calculation of its effectiveness, future changes and modifications are not presumed which may happened during the realisation [1].

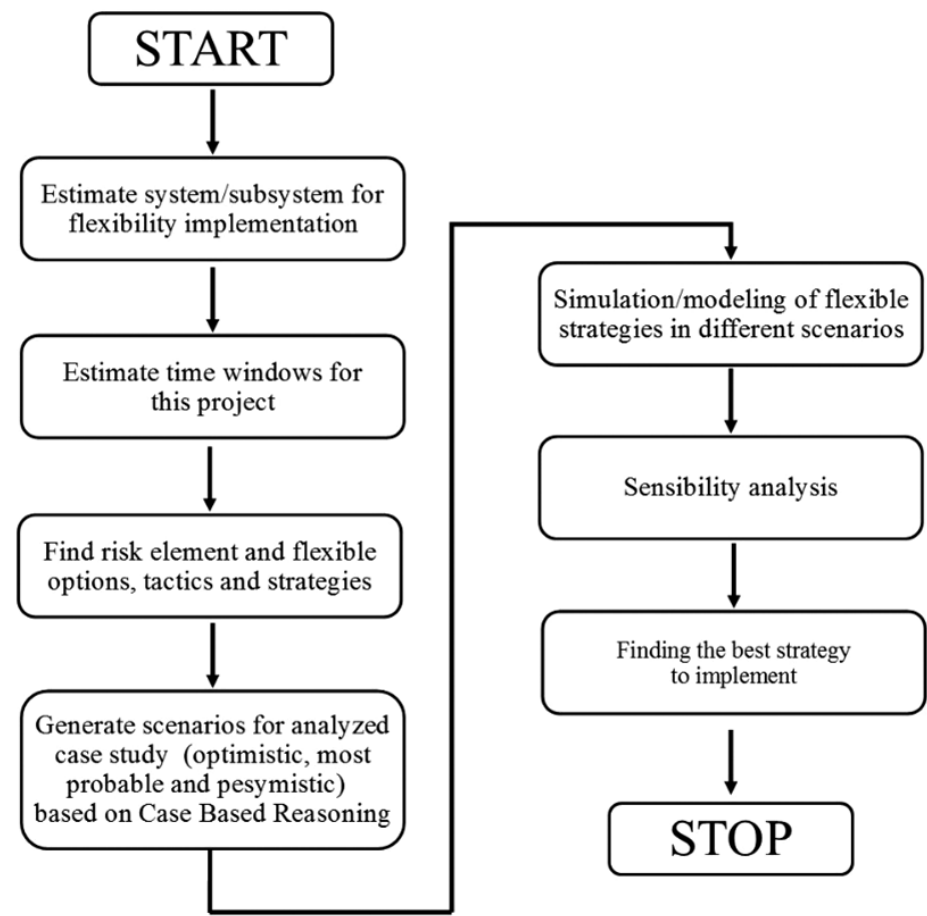

Fig. 1. Algorithm/procedures for introducing a flexible approach when planning infrastructure investments

Some reviews of the literature say that predicting the future is burdened with considerable uncertainty, in which case, the method of updated cash flows that are currently considered the best methods for assessing economic efficiency are only secondary tools, this is because they do not allow exploited opportunities or protect against the risk of following strategy. In fact, during the analysis of the traditionally used methods of assessing the effectiveness of investment, it is hard not to notice that these methods ignore the possibility of introducing flexibility in the project and are not able to take into account or properly assess options that can follow when determining the appropriate strategy.

\section{Traditional methods of assessing the effectiveness of investments}

In practice, there are many traditional techniques for calculating the financial viability of a project, starting from the most simple and intuitive and ending with some very complex methods. In the nineteen-thirties, I. Fisher developed the basis for the efficiency assessment 
methods used today [6]; thus, today they are called 'traditional' as over the decades, they have gained widespread acceptance and have entered into business practice.

Unquestionably, the most important methods of assessing financial performance are widely described in literature - these two methods are based on the updated time value of money, they include the method of net present value (NPV) and the internal rate of return (IRR); however, simple, static methods are also widely used.

In an article which was reviewed by the methods for assessing the economic efficiency can be differentiated on the basis of two main parameters which must be taken into account when calculating the profitability of projects, namely, time and risk. These two factors are key because when making investment decisions, there is firstly a need to prepare the bill of financial benefits - these must take into account the change in the time value of money, and secondly, to expect that the assumed effects may occur but not necessarily.

\subsection{Time factor approach}

The first criterion for the classification methods is the time factor and more specifically, changes in the value of money over time. Thus, these methods can be divided into two groups - 'simple' (static) which do not include changes in the value of money and 'discount' (dynamic) [12], which take this factor into account.

\subsubsection{Statistical methods}

Statistical methods are a group of intuitive, simple methods used to get an overview about the economical investment. They are used mainly in the early stages of the investment process and their application enables their simplicity and clarity [1].

The first statistical method, which is fairly common in investment processes for reconstructions and modernisations, is the bill of comparative costs. The result presents an opportunity to choose the best investment option from all the variants which are characterised by the same advantages but differ with regard to the total financial expenditure incurred by the investor. Under these conditions, the decision criterion of optimisation is to minimise the cost [11].

The second method, commonly used as a comparative account of profitability, though there are the many variations and names, is the so-called accounting rate of return. This is expressed as a percentage and it is the ratio of the accounting profit from investments and involved capital [8] - the investment is deemed acceptable if it reaches the minimum threshold set by the investor.

The main advantage of this method is its simplicity and ease of use, since it is based on data included in the financial statements. Unfortunately, this is also its drawback as the actual cash flows are used. Indeed, basing the decision on book values, e.g. the net profit, should be considered as one of the major errors of investment planning [5].

The third static method most commonly used in practice is the method of payback period. This is based on the time period after which the proceeds of the investment project equal the expenses incurred for this project, of course, the shorter the time, the better. The 
most important advantage of this method is the fact that the result is given in years - this is readable and understandable for the potential investor. However, the drawback is the lack of information about the profitability of the project and the difficulty of applying method because the expenditures are incurred also during the investment operation [10].

\subsubsection{Dynamic methods}

The basic feature of these methods is the inclusion of the time factor, specifically, changes in the value of money over time and the timing of receipts and payments related to the preparation, implementation and operation of investment [3].

The literature highlights the two most important dynamic methods, known collectively as methods of discounted cash flow DCF.

\subsubsection{The method of net present value NPV}

This method is based on the ratio of expense flows to the present value of the future investment income which is defined as the difference between the sum of the discounted cash flow achieved during the life of the investment and the amount discounted for the same year of investment for the implementation of the investment project [10].

The basic criterion for the decision is a positive NPV account value. This is a very flexible economic instrument because its formula may be adjusted and converted according to the specifications of a particular investment environment [1].

\subsubsection{Internal rate of return IRR}

During calculations of the net present value, it is necessary to determine the discount rate assumed by the investor. On the other hand, when the investor is interested in ensuring at which discount rate the investment outlays in a given period returns, he can use a tool which is the method of Internal Rate of Return.

To put it simply it can be said that the internal rate of return is the discount rate at which the NPV of the investment project is equal to zero. Therefore, the IRR is equivalent to the discount rate at which, during the analysis of the updated value of financial income is equal to the discounted value of the investment. In other words, the capital outlay pay for itself.

\subsection{Recognition of risk factor}

As previously mentioned, any investment involves risk; therefore, risk should be taken into account during the analysis of the economic efficiency of each project.

\subsubsection{Direct risk factor recognition}

The method of equivalent of certainty CE states that the expected cash flows are modified to reflect the risks associated with [9]. Thus, the flows that have a greater risk are reduced - this is due to the need to recognise a 'non-risk equivalent' [9] of risky funds invested in the project. 
During calculations, classical equation NPV is modified in risky cash flows and they are replaced with equivalents.

This method is extremely advantageous when the cash flows of the project for different periods have different degrees of risk - this is a common phenomenon, because the cash flow is subjected to a greater risk the further the project progresses.

The second method of evaluating the economic efficiency, which in its calculation takes into account the risk method is Risk Adjusted Rate RADR. Like the previous method, this also introduces a risk factor for the calculation of NPV.

The basic principle of this method is based on the assumption that investment projects burdened with bigger risk should have a higher discount rate than projects with less risk. What means that with an increase in the risk the discount rate is increasing as well as the investor rate of return on a risky investment.

\subsubsection{Indirectly included risk}

The methods of directly taking into account the risk analysis are based on calculations of NPV ratio. By contrast, the literature describes methods for the subject which are used in practice and indirectly take risk into account. The results of these methods include the measured standard deviation risk and information about possible changes in factors affecting the NPV [2].

Sensitivity analysis is an analysis in which on the understanding that changes in different variables (e.g. price, expenses, cash flow) included in the calculations show the profitability of the investment project. The basic premise of this method is characterised by the fact that the future is so unpredictable that the actual values of the variables will be at the turn of time deflecting from the goals. As a result of this, it can be determined which variables have a real impact on the economic value of the investment project - this eliminates variables that are characterised by mean volatility but have a negligible impact on the final profitability of the investment.

Another discussed method is scenario analysis - this takes into account the effect of several variables at once on the value of the project during the calculations. Usually, three scenarios that contain different combinations of parameters affecting the value of the project are factored in (optimistic, pessimistic, and most likely) during the calculations.

The third type of these methods are simulation methods - these are a group which include the Monte Carlo method, which takes into account multiple combination design parameters that have influence on the final value of the investment. The Monte Carlo method is the most common method within this group. This method is subject to a simulation formula of NPV or IRR in the following manner [4]: a) the selection of the parameters considered at risk; b) determine the probability of individual variables and the relationships between them; c) random selection of variables; d) the calculation of the net cash flows for each year and then the NPV of the project; e) repeat calculations 'c)' and 'd)' several hundred times; f) the result is obtained in the form of the probability distribution of NPV. 
The final method among the indirect risk-based methods is decision tree analysis DTA. This method graphically shows possible investment decisions that can be taken at different times during the project. At the same time, it shows the relationship between decisions and give each of them amount of probability. Each variant that is entered onto decision tree is multiplied by the gain from the project and shows the distribution of benefits relating to individual decisions.

\section{Conclusions}

The implementation of investment projects with the rapid pace of changes in the conditions of the project is extremely difficult. Hence, it even becomes indispensable creation and implementation of investments in idea of the flexibility. Flexible approach in this situation is characterized by the formation of the initial action plan, that adapts to changing market conditions, evolving course of the project in such a way as to limit expansion, deferment during implementation, change parameters or in extreme cases withdraw from the investment.

In current assessments of the costs of investment through the life cycle of a project (starting from the design stage through the construction stage and finishing with exploitation) was assuming at most a changeability of rate of returns on investment. However, the accepted period for analyses amounts to around 30 years, and consequently arbitrarily attempting to assess the level of costs can be a process that is riddled with errors. An alternative solution could be to include in calculation cost the risk factors what could have an impact on cost values in every stage of investment. The authors of the present article, however, propose introducing flexibility i.e. the consideration of different scenarios which anticipate changes in the configuration of parameters of the object in the cycle of its life. Next proposal is using a multi-criteria approach, which enables calculating quantitative and qualitative criteria influencing the size of life cycle costs at final selecting variant.

Traditional methods for assessing economic efficiency capture investment flows in a very static manner. Even if a few forecasts of development of the project are considered, there are still assumed predetermined values of financial flows in them. Therefore, they cannot be used in the analysis of investments using flexible tools, as when having to deal with different elastic options, the size of future cash flows is closely dependent upon what decisions that will be taken in the future.

Due to the variety and various features of methods discussed above of investment analysis using the tool of flexibility should not be limited to just one, instead, a few should be used as this would provide a full picture of the situation of the project under assessment. In addition, at each stage of the project, from analysis through to implementation and operation, these methods should be used to protect projects from the risk and to enable the investor to seize opportunities that arise in an uncertain future. 
In examinations of authors of the article are basing on the scenario analysis expanded on simulation method. The assessment of these methods are made by joining the discounted cash flows NPV and IRR.

\section{References}

[1] Dziworska K., Decyzje inwestycyjne przedsiębiorstw, Uniwersytet Gdański, Gdańsk 2000.

[2] Pluta W., Budżetowanie kapitatów, Polskie Wydawnictwo Ekonomiczne, Warszawa 2000.

[3] Ziarkowski R., Opcje rzeczowe oraz ich zastosowanie w forlmutowaniu i ocenie projektów inwestycyjnych, PRACE NAUKOWE Akademii Ekonomicznej im. Karola Adamieckiego w Katowicach, Katowice 2004.

[4] Copland T.E, Keenan P.T., How Much is Flexibility Worth?, The McKinsey Quarterly No. 2, 1998, 38-49.

[5] Dimkoff G., Avoid Major Mistakes In Capital Budgeting, Facilities Design \& Mangement, February 1994.

[6] Fisher I., The Theory of Interest, Macmillan, New York 1930.

[7] Gajzler M, Kośmieja M, Pasławski J., Elastic designing the road infrastructure in example, Czasopismo Techniczne, 2-B/2014.

[8] Lumby S., Investment Appraisal and Financing Decision, Chapman\&Hall, London 1991.

[9] Malinowski A., Tarapata Z., Ocena projektów gospodarczych, Defin, Warszawa 2001.

[10] Marcinek K., Finansowa ocena przedsięwzięć inwestycyjnych przedsiębiorstw, Akademia Ekonomiczna, Katowice 2001.

[11] Czechowski L., Dziworska K., Gostrzowska-Drzewicka T., Górczyńska A., Ostrowska E., Projkety inwestycyjne, ODDK, Gdańsk 1999.

[12] Nowak E., Pielichaty E., Poszwa M., Rachunek opłacalności inwestowania, PWN, Warszawa 1999. 